\title{
Synthesis, Structure, and Cytotoxicity Studies of Oxidovanadium(IV and V) Complexes bearing Chelating Phenolates
}

David M. Miller-Shakesby ${ }^{a}$, Shubhanchi Nigam ${ }^{a, b}$, Adam Brookfield ${ }^{\mathrm{c}}$, Eric J. L. McInnes ${ }^{\mathrm{c}}$, Timothy J. Prior $^{a}$, Stephen J. Archibald ${ }^{a, b *}$ and Carl Redshaw ${ }^{a *}$

${ }^{a}$ Department of Chemistry, University of Hull, Cottingham Road, Hull, HU6 7RX, UK.

${ }^{b}$ Positron Emission Tomography Research Centre, University of Hull, Cottingham Road, Hull, HU6 7RX, UK.

${ }^{c}$ EPSRC UK National EPR Facility, School of Chemistry and Photon Science Institute, The University of Manchester, Oxford Road, M13 9PL, Manchester, UK.

\begin{abstract}
The interaction of [VO(acac) 2 ] with 2,6-bis(hydroxymethyl)-4-methylphenol ( $\left.\mathbf{L}^{\mathbf{1}} \mathrm{H}_{3}\right)$ or 6,6'methylenebis(4-tert-butyl-2-(hydroxymethyl)phenol) $\left(\mathbf{L}^{2} \mathrm{H}_{4}\right)$ in refluxing toluene afforded, following work-up in ethanol, the complexes $\left[\mathrm{VOL}^{1}\right]_{2}(\mathbf{1})$ and $\left.\left\{[\mathrm{VO}(\mathrm{acac})(\mathrm{HOEt})](\mathrm{VO}) \mathbf{L}^{2}\right]\right\}_{2}$ (2), respectively. Use of 4-[3,5-bis(2-hydroxyphenyl)-1,2,4-triazol-1-yl]benzoic acid $\quad\left(\mathbf{L}^{3} \mathrm{H}_{2}\right)$ or 4-[3,5-bis(2hydroxyphenyl)-1,2,4-triazol-1-yl]benzosulfonic acid $\left(\mathrm{L}^{4} \mathrm{H}_{2}\right)$ with $\left[\mathrm{VOCl}_{3}\right]$ in refluxing acetonitrile, followed by methanol and THF work-up, afforded the complexes $\left[\mathrm{Et}_{3} \mathrm{NH}\right]\left[\mathrm{VO}(\mathrm{OMe}) \mathbf{L}^{3}\right]_{2}(3)$ and $\left[\mathrm{Et}_{3} \mathrm{NH}\right]\left[\mathrm{VO}(\mathrm{OMe}) \mathbf{L}^{4}\right]_{2}$ (4), respectively. The interaction of $\left[\mathrm{VOSO}_{4}\right]$ and $\mathbf{L}^{3} \mathrm{H}_{2}$ in refluxing acetonitrile afforded, with extraction into methanol, the complex $\left[\mathrm{VO}(\mathrm{OMe}) \mathbf{L}^{3}\right]_{2}(5)$. The molecular structures of 2, 3 and $\mathbf{5}$ have been determined; the structure of $\mathbf{1}$ has been reported previously. The complexes in this study have been determined to be of low toxicity using in vitro cell assays with $50 \%$ cytotoxicity values $\left(\mathrm{CC}_{50}\right)$ values in the range $56-126 \mu \mathrm{M}$.
\end{abstract}




\section{Introduction}

Coordination compounds of vanadium continue to attract attention given their potential applications in areas such as supramolecular chemistry, energy applications and catalysis including olefin polymerization, ring opening polymerization, and oxidation catalysis. [1] There is also much interest in their medicinal/biological properties, including as insulin mimics, and a number of reviews have appeared over the last couple of decades. [2] In the field of metal-based (non-Pt) anti-cancer agents, a number of early transition metal systems have shown promise. [3,4] It is desirable that the metals employed are both earth abundant and cheap. With this in mind, we note that vanadium complexes have been shown collectively to possess a number of the essential effects on cancerous cells required for an effective anti-cancer agent, either solely or in combination with other anti-cancer agents. [5] As an example, a series of peroxovanadium complexes have shown reduction in cellular growth rate in neuroblastoma NB41 and glioma C6 cell lines. [6] On the other hand, other peroxovanadates that form in C3H10T1 fibroblasts in situ have been shown to actually cause proliferation of cancerous cells. [7] Tests have shown that vanadium complexes block the $G_{2}-M$ transition of the cell cycle, so mitosis never occurs. [6] Furthermore, vanadium complexes have been shown to induce protein tyrosine phosphorylation in a number key proteins that are linked to the production of highly reactive oxygen species that cause damage to DNA. [8-11] This causes an increase in the production in reactive oxygen species that eventually leads to cell necrosis. Vanadium has also been shown to inhibit phosphotyrosine phosphatases (PTPs), [12,13] which regulate signal transduction pathways causing apoptosis. [14,15]

There are a few examples of organisms that have grown resistant to the effects of vanadium by altering the way in which they control protein tyrosine phosphorylation. [16] However in combination with other anti-cancer agents, vanadium has been shown to reverse drug resistance in a number of cancers. For example, sodium orthovanadate has been shown to re-sensitize CEM/VLB 100 cells to vinblastine. [17] Furthermore, when vanadium is bound by a chelating agent, it actually reverses the resistance of human ovarian cancer cells to cisplatin, allowing the 'gold-standard' anticancer treatment to destroy the cancerous cells. [18] 
We note that Schiff base complexes of $\left[\mathrm{V}^{\mathrm{IV}} \mathrm{O}\right]^{2+}$ have recently been screened against human tumour cell lines (HeLa and HCT-15), and, for some of the complexes, activities greater than cisplatin were observed. [19] Entry into this high-valent vanadium chemistry is via the use of the starting materials $\left[\mathrm{VO}(\mathrm{acac})_{2}\right],\left[\mathrm{VOCl}_{3}\right]$ and $\left[\mathrm{VOSO}_{4}\right]$; the use of $\left[\mathrm{VO}(\mathrm{acac})_{2}\right]$ has been reviewed. [20] Previously, we have noted promising cytotoxicity results using phenolic macrocycles (calixarenes) bearing oxidovanadium groups, [21] and we now report our results on a number of non-macrocyclic phenolic systems, see scheme 1 . These include the deferasirox chelator $\left(\mathbf{L}^{3} \mathrm{H}_{2}\right)$ for which the iron(III) complex has previously been evaluated for anti-cancer activity. [22]

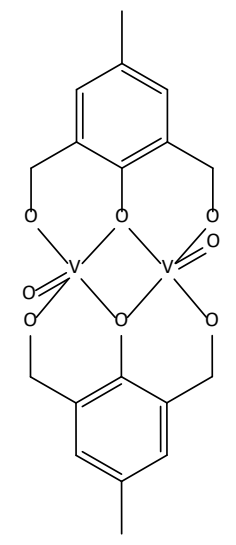

1

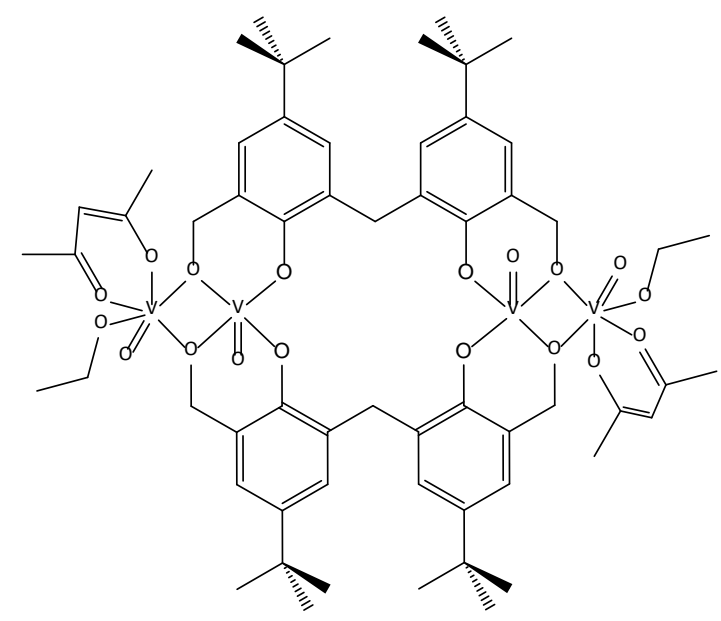

2

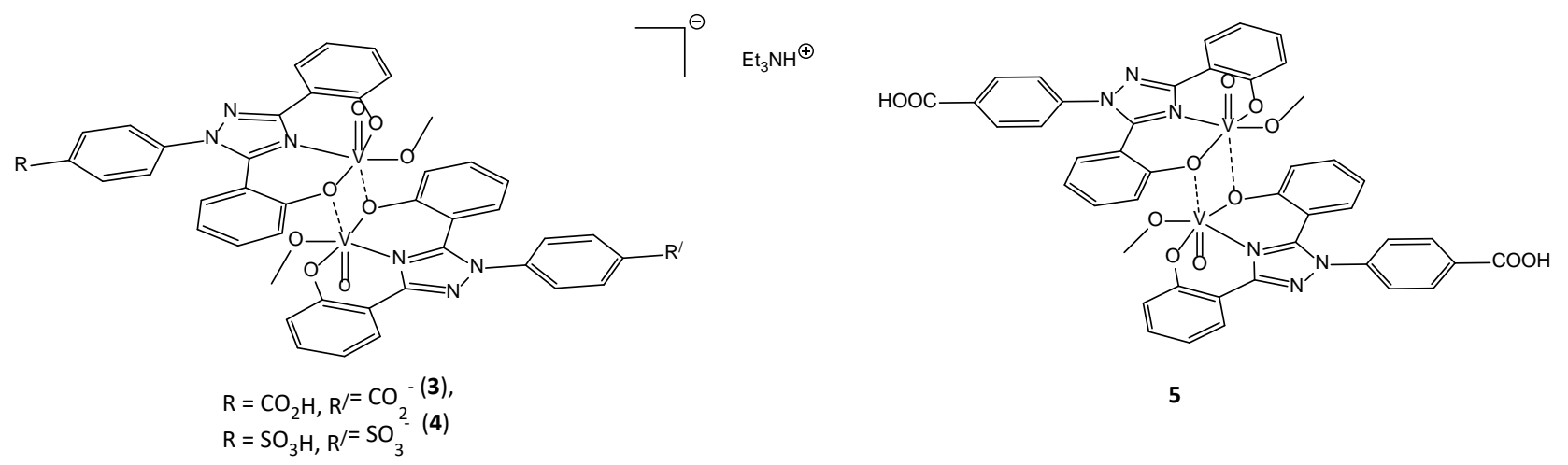

Scheme 1. Oxidovanadium(IV and V) compounds $\mathbf{1}$ - $\mathbf{5}$ studied herein.

\section{Results and Discussion}




\subsection{Synthesis and molecular structures}

The reaction of oxidovanadium(IV) acetylacetonate and 2,6-bis(hydroxymethyl)-4-methylphenol in an equal molar ratio in refluxing toluene over 2 h, following work-up, afforded a dark blue solution, from which on standing (24 h) under air (i.e. evaporation) red crystals formed in a yield of 65\%. The structure of this red product was identified as the previously reported complex [VOL $\left.{ }^{\mathbf{1}}\right]_{2}$ (1), [23] (see ESI, Fig. S1). Over time (6 - 8 weeks), the red product decomposed to a mud-brown colour, so batches of this complex are best kept in a glovebox until they are required for subsequent use. This decomposition process was determined by Chaudhury et al. [23] to be the formation of an oligomeric aldehydecoordinated vanadium(IV) complex.

We note that use of the same pro-ligand, but with oxidovanadium(IV) sulfate and varying quantities of triethylamine, results in similar binding of dioxovanadium(V) or oxovanadium(IV) groups as recently observed by Mikuriya et al. [24]; three different structures I, II, and III (see Scheme 2) were isolated and structurally characterized.
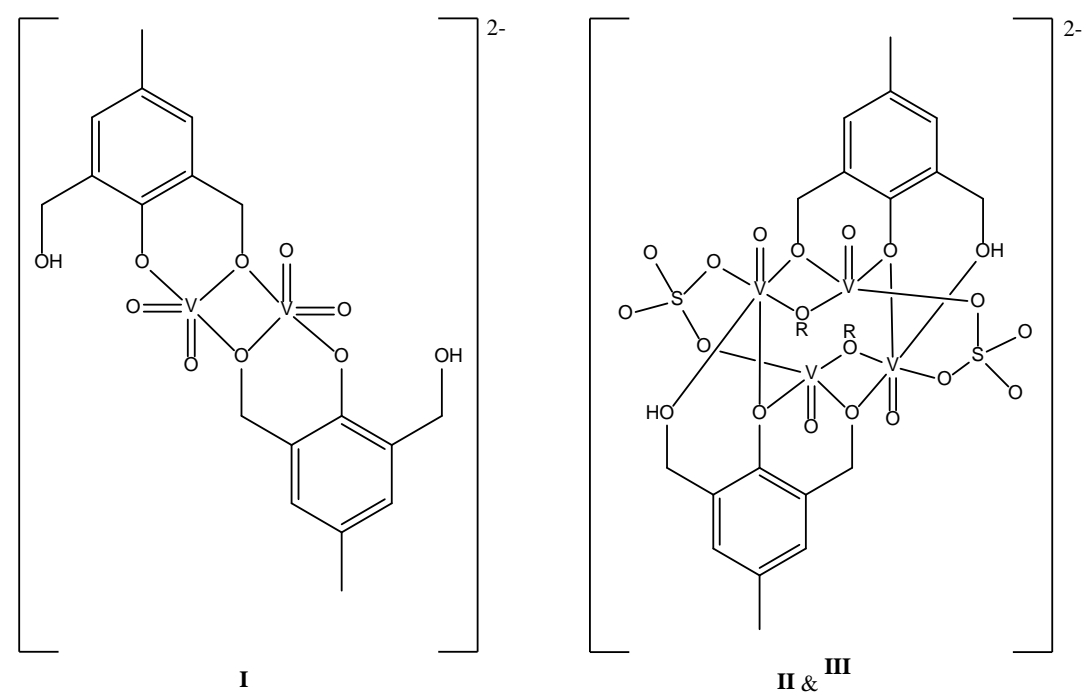

II: $\mathrm{R}=\mathrm{Me}$ 
Scheme 2. Structural motifs I and II observed by Mikuriya et al. [24]

The synthesis of tetra-nuclear 2 was carried out under anaerobic conditions. The pro-ligand 6,6'methylenebis(4-tert-butyl-2-(hydroxymethyl)phenol) $\left(\mathbf{L}^{2} \mathrm{H}_{4}\right)$ was reacted with an excess of oxidovanadium(IV) acetylacetonate in refluxing toluene over 48 h. Following work-up (extraction into warm ethanol), tiny dark green crystals grew over the course of several weeks (in $24 \%$ yield). Despite the weakly scattering nature of the crystals, it proved possible to obtain data of sufficient quality to identify the connectivity. A view of the molecule is shown in Figure 1, with alternative views provided in the ESI (Fig. S2). 


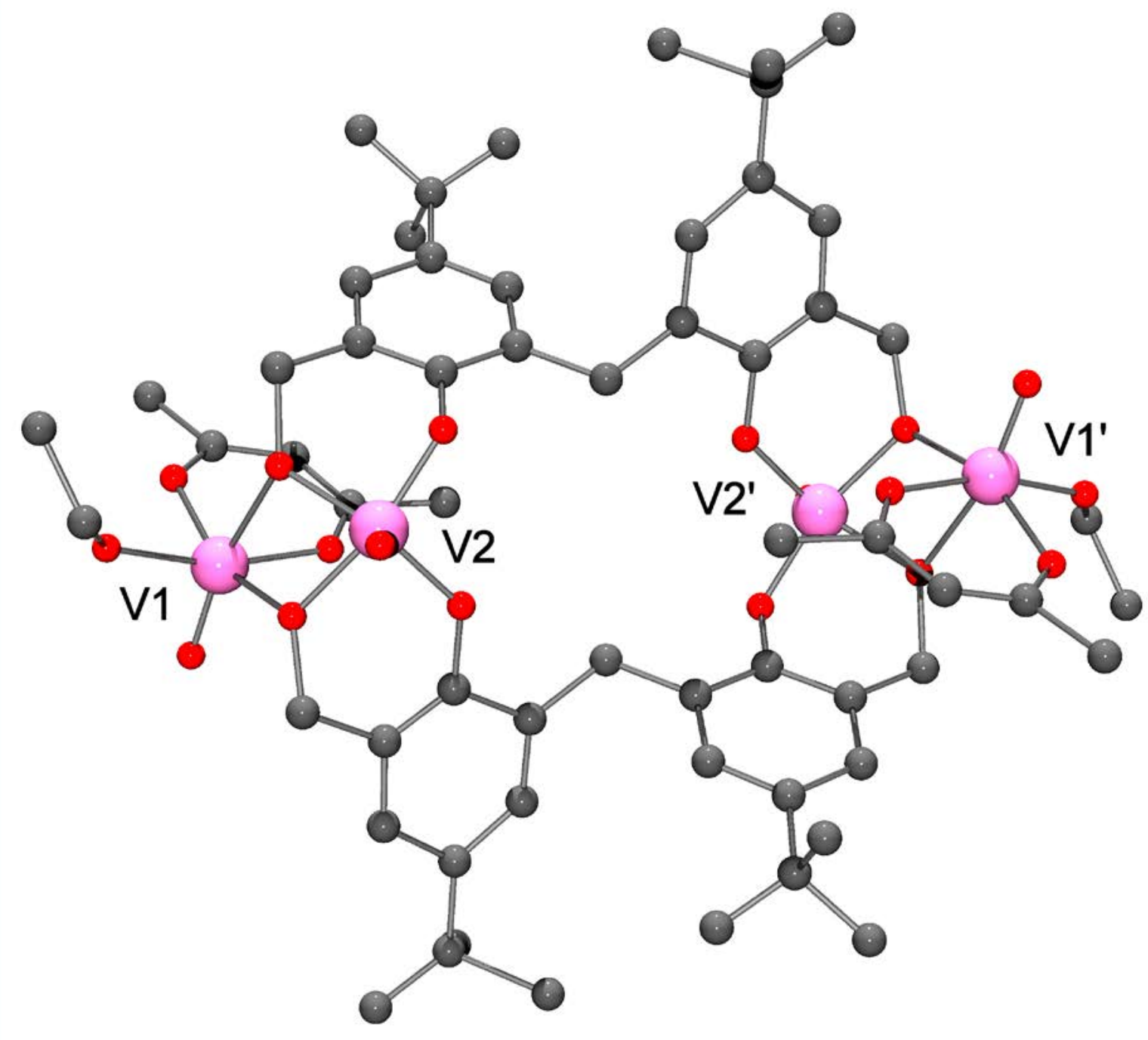

Figure 1. Molecular structure of $\left.\left\{[\mathrm{VO}(\mathrm{acac})(\mathrm{HOEt})](\mathrm{VO}) \mathbf{L}^{2}\right]\right\}_{2}$ (2). Atoms labelled with the prime symbol are generated using the symmetry operation 1-x,-y, 1-z.

The structure consists of two deprotonated pro-ligands $\mathbf{L}^{2}$ bridged by four vanadium atoms forming a centrosymmetric dimer of formula $\left.\left\{[\mathrm{VO}(\mathrm{acac})(\mathrm{HOEt})](\mathrm{VO}) \mathbf{L}^{2}\right]\right\}_{2}$ (2). The coordination environment at the outer, pseudo octahedral oxidovanadium centres is completed by an acac and an ethanol ligand; the $\mathrm{V}$ - O bond lengths of $c a .2 .0 \AA$ are longer than that observed in related ethoxide complexes (V - O 
typically ca. $1.74 \AA$. [25] This is consistent with the presence a $v(\mathrm{OH})$ at $3398 \mathrm{~cm}^{-1}$ in the IR spectrum; strong stretches at 1015 and $958 \mathrm{~cm}^{-1}$ are assigned to the $v(\mathrm{~V}=\mathrm{O})$ groups. In the MALDI mass spectrum, the molecular ion is observed at 1292.12. The two inner oxidovanadium centres (V2/V2') are 5coordinate and adopt distorted squared-based pyramidal geometries. The $\tau$ value here, which has been defined as the degree of trigonality, is 0.357 , and this confirms here the geometry is close to square pyramidal rather than trigonal bipyramidal. [26] In terms of oxidation states, the observed ligation and charge balance is consistent with a mixed-valence system for which the inner oxidovanadium centres $\left(\mathrm{V} 1 / \mathrm{V1}^{\prime}\right)$ are $\mathrm{V}(\mathrm{IV})$ and the outer oxidovanadium centres are $\mathrm{V}(\mathrm{V})$.

In the packing of $\mathbf{2}$, there are no classical hydrogen bonds between the molecules of $\mathbf{2}$ in the solid state. The crystal packing (see figure 2) involves assembly of the molecules in puckered sheets that extend in the $x z$ plane. These sheets are stacked so as to generate channels that run through the structure parallel to the crystallographic $a$ direction and these comprise $26 \%$ of the crystal volume. These are filled with disordered solvent.

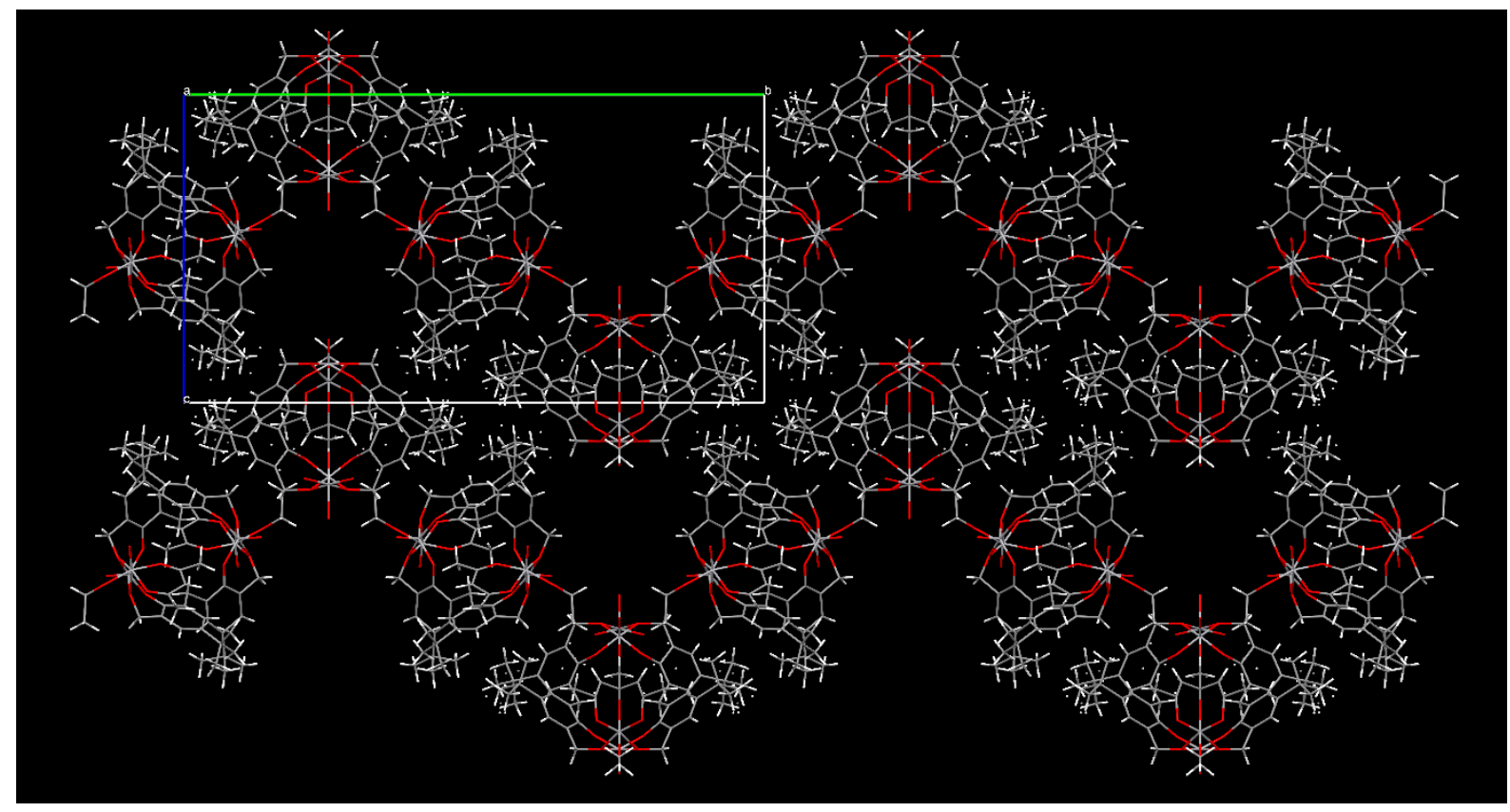

Figure 2. Crystal packing of $\mathbf{2}$ shown along the $a$-direction. Channels parallel to $a$ are clearly visible. 
Again, the synthesis of $\mathbf{3}$ was carried out under anaerobic conditions. The triazole pro-ligand, $\mathbf{L}^{3} \mathrm{H}_{2}$, was suspended in acetonitrile and a slight excess (1.2 equivalents) of vanadium(V) oxytrichoride was added. After initial extraction into $\mathrm{MeOH}$ failed to yield crystals, a following work-up (extraction into THF) gave a dark blue/black solid, which was then taken up in THF. Standing for $48 \mathrm{~h}$ at $-20^{\circ} \mathrm{C}$ afforded dark blue crystals of [ $\left.\mathrm{Et}_{3} \mathrm{NH}\right]\left[\mathrm{VO}(\mathrm{OMe}) \mathbf{L}^{3}\right]_{2}$ (3) (65\% yield). The related complex 4 was prepared in a similar manner using $\mathbf{L}^{4} \mathrm{H}_{2}$, in an isolated yield of 56\%. In the IR spectra of $\mathbf{3}$ and $\mathbf{4}$, a strong stretch at 959 and $962 \mathrm{~cm}^{-1}$, respectively is assigned to the $v(\mathrm{~V}=\mathrm{O})$ groups. In the MALDI mass spectra, the molecular ion are observed at 875.99 and 948.03 for $\mathbf{3}$ and $\mathbf{4}$, respectively.

Complex 3 crystallises in the space group $P c$ and the asymmetric unit comprises a single dimeric $\mathrm{V}$ complex (Figure 3) a molecule of methanol, one of water, one of diethylether, and a triethylammonium cation. The V complex has carboxyl groups at each end; statistically one of these is protonated (ie formally one is $\mathrm{COOH}$ and one is $\mathrm{COO}^{-}$at random). Each vanadium is coordinated by one nitrogen in the triazole ring and two deprotonated oxygens from phenol units in the pro-ligand $\mathbf{L}^{3} \mathrm{H}_{2}$. The coordination at each metal is completed by a methoxide ligand and an oxide forming an oxidovanadium group. The result is that both vanadium ions exhibit a distorted octahedral geometry; there is a long (2.334 $\AA$ ) V-O interaction to a phenoxide oxygen of a second $\mathbf{L}^{3}$ ligand, trans to the oxidovanadium, such that a dimer is formed (see Figure 3 V2-O1). Three additional non-coordinated methanol molecules and a single protonated triethylammonium unit complete the structure, the presence of the latter means that the dimeric anion must be of mixed valence, i.e. $\mathrm{V}(\mathrm{V})$ and $\mathrm{V}(\mathrm{IV})$. Details of the crystal structure can be found in Table 2 . 


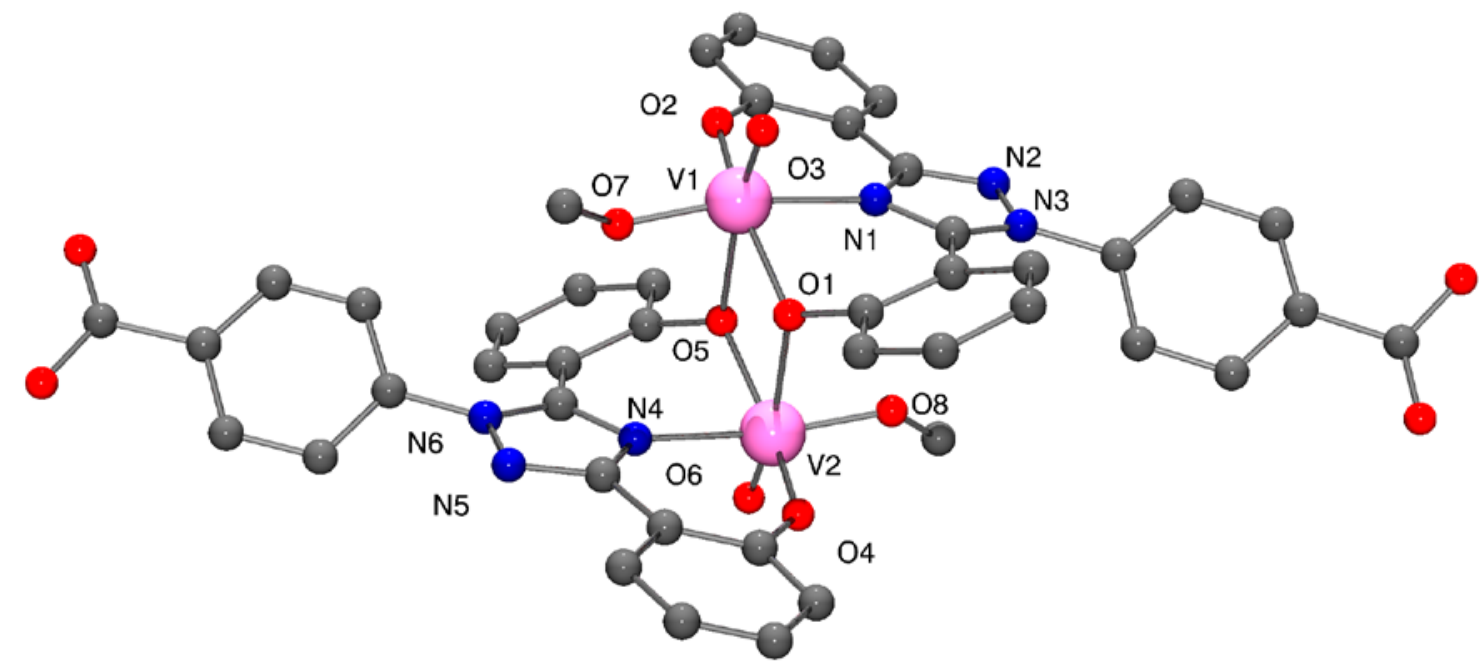

Figure 3. Asymmetric unit of 3. Selected bond lengths $(\AA)$ and angles $\left({ }^{\circ}\right)$ : V1=O3 1.593(9) $\AA$, V1N1 2.102(10) Å, V1-O2 1.886(8) Å, V1-O1 1.955(8) Å, V1-O7 1.792(9) A,, V1-O5 2.333(9) Å,

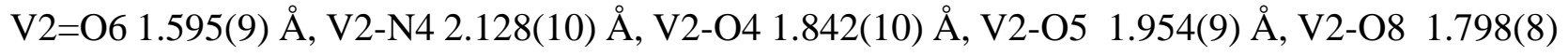
Å, V2-O1 2.299(9) Å.

In 3, the carboxylic acid on one molecule forms a hydrogen bond to carboxylate on an adjacent molecule forming a $\mathrm{COOH}^{\cdots-}$ OOC hydrogen bond. The very close approach of the two oxygen atoms $(\mathrm{O} \cdots \mathrm{O}$ distance is $2.4554(1) \AA)$ is consistent with this hydrogen bond. These classical hydrogen bonds link the complexes into tapes that run parallel to the [101] direction. Further nonclassical hydrogen bonds $(\mathrm{C}-\mathrm{H} \cdots \mathrm{O})$ stack these tapes parallel to the $a$ direction. In between the chains the ether, water, and triethylammonium cation for a hydrogen-bonded cluster. For a view of 3 down the [010] direction, see Figure 4. 


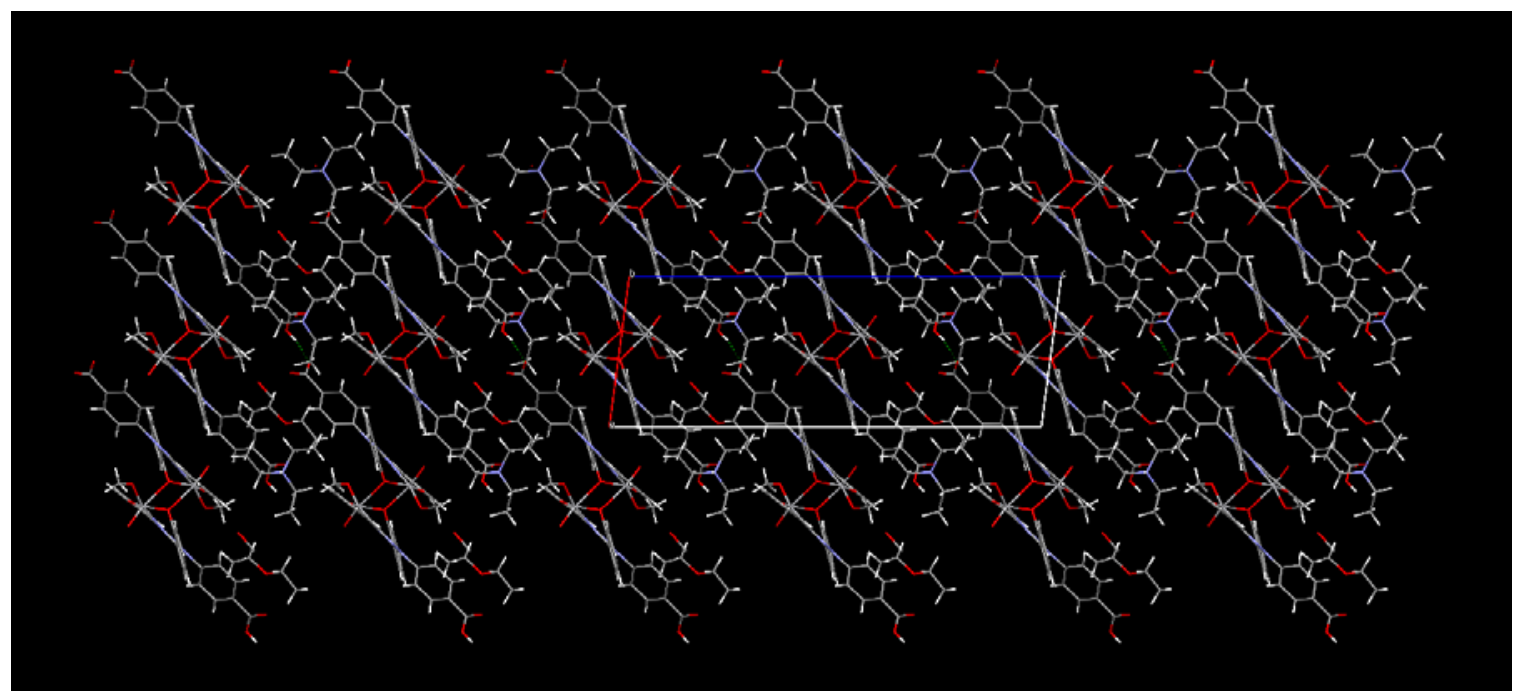

Figure 4: View of 3 down the [010] direction.

The interaction of $\left[\mathrm{VOSO}_{4}\right]$ and $\mathbf{L}^{3} \mathrm{H}_{2}$ in refluxing acetonitrile afforded, following extraction into methanol, the complex $\left[\mathrm{VO}(\mathrm{OMe}) \mathbf{L}^{3}\right]_{2}$ (5). Given the nature of the ligands present, the ${ }^{1} \mathrm{H}$ NMR spectrum of 5 mostly comprises of a complex aromatic region (see figure S5 for an expansion of this region), together with a single at $\delta 3.28$ for the methoxides; the acid proton is assigned to a very broad resonance over the range 10.55 to $8.30 \mathrm{ppm}$ (in the parent ligand, it appears as a broad singlet at c.a. $11.4 \mathrm{ppm}$ in $\mathrm{dmsod}_{6}$ ). Light brown crystals of 5 suitable for an X-ray diffraction study were obtained via diffusion of $\mathrm{CH}_{2} \mathrm{Cl}_{2}$ and methanol. The molecular structure is shown in Figure 5, with selected bond lengths and angles given in the caption. 5 crystallises in the centrosymmetric space group P-1 with a half of one dimer and one molecule of methanol within the asymmetric unit. The oxidovanadium(V) cation is coordinated by three atoms from the deprotonated phenolate and one molecule of methanol to give a distorted octahedral geometry about the metal. Each dimer is 
generated by the centre of symmetry and the phenolate oxygen atoms bridge between two identical oxidovanadium(V) cations. These oxygen atoms form one short bond and one long bond to vanadium $\left(\mathrm{V}(1)-\mathrm{O}(1)=1.9498(12)\right.$ and $\mathrm{O}(1)-\mathrm{V}(1)^{\mathrm{i}}$ 2.3479(12) $\AA$ where $\left.\mathrm{i}=1-\mathrm{x}, 1-\mathrm{y}, 1-\mathrm{z}\right)$. Each carboxylic acid is not deprotonated and this forms a hydrogen bond to unbound methanol. This hydrogen bonding sustains infinite chains formed from $\mathrm{C}_{4}^{4}(12)$ embraces of two carboxylic acids bridge by two methanol molecules (See Fig. S3, ESI).

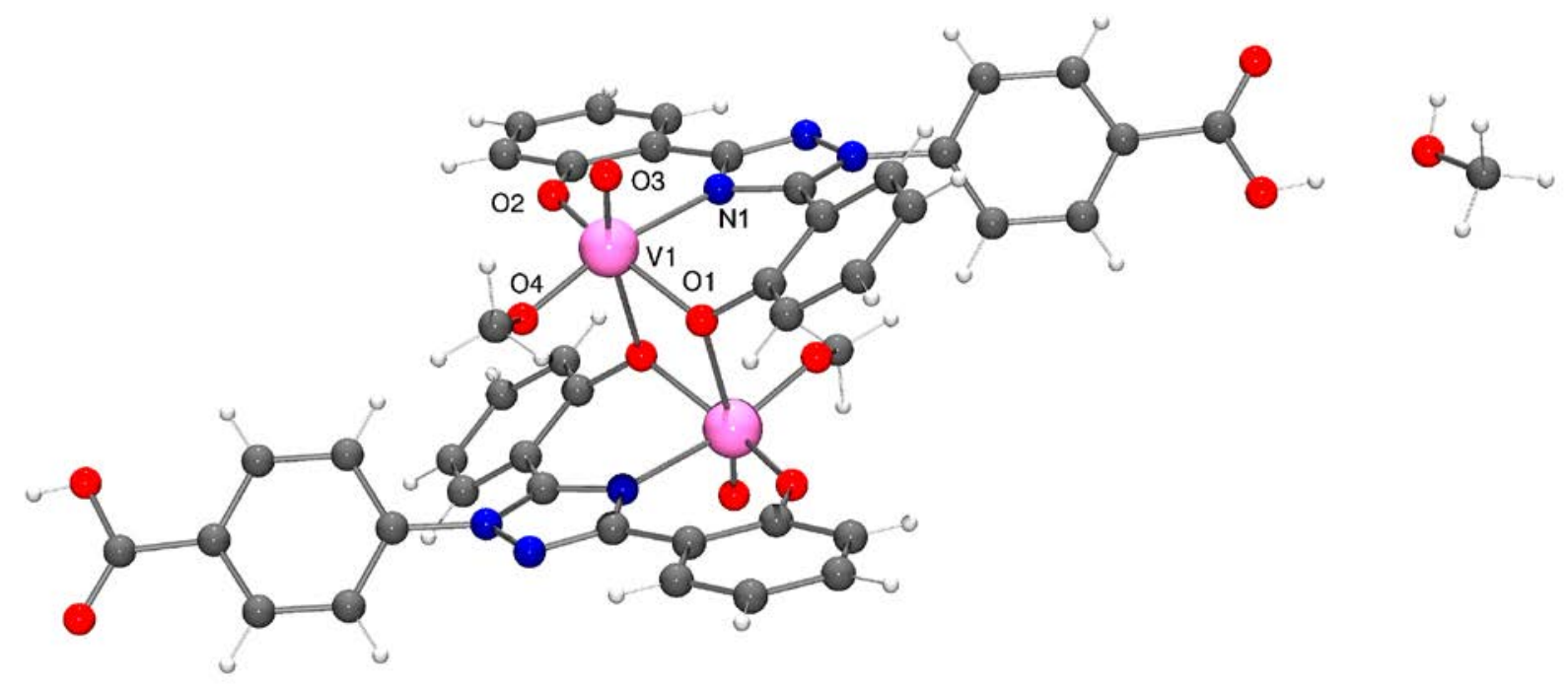

Figure 5. Asymmetric unit of 5. Selected bond lengths $(\AA)$ and angles $\left({ }^{\circ}\right): \mathrm{V} 1-\mathrm{O} 1=1.9498(12)$ and $\mathrm{O} 1-\mathrm{V} 1^{\mathrm{i}} 2.3479(12), \mathrm{V} 1-\mathrm{O} 2=1.8474(12), \mathrm{V} 1-\mathrm{O} 3=1.5963(13), \mathrm{V} 1-\mathrm{O} 4=1.7940(13), \mathrm{V} 1-\mathrm{N} 1=$ 2.1265(15); O1—V1—O2 = 153.05(6), N1—V1—O4 = 167.29(6), O1-V1—O3 = 96.67(6).

In the packing of 5, the complex and methanol are involved in an extended hydrogen-bonded network in the solid state. The free carboxylic acid group of each complex is linked to another in an $\mathrm{R}^{4}{ }_{4}(12)$ embrace that involves two molecules of methanol, see figure 6 . These interactions form tapes along the 
[212] direction. Further $\mathrm{C}-\mathrm{H} \cdots \mathrm{O}$ interactions hold the tapes together in the solid to make a dense hydrogen-bonded array, see figure 7.

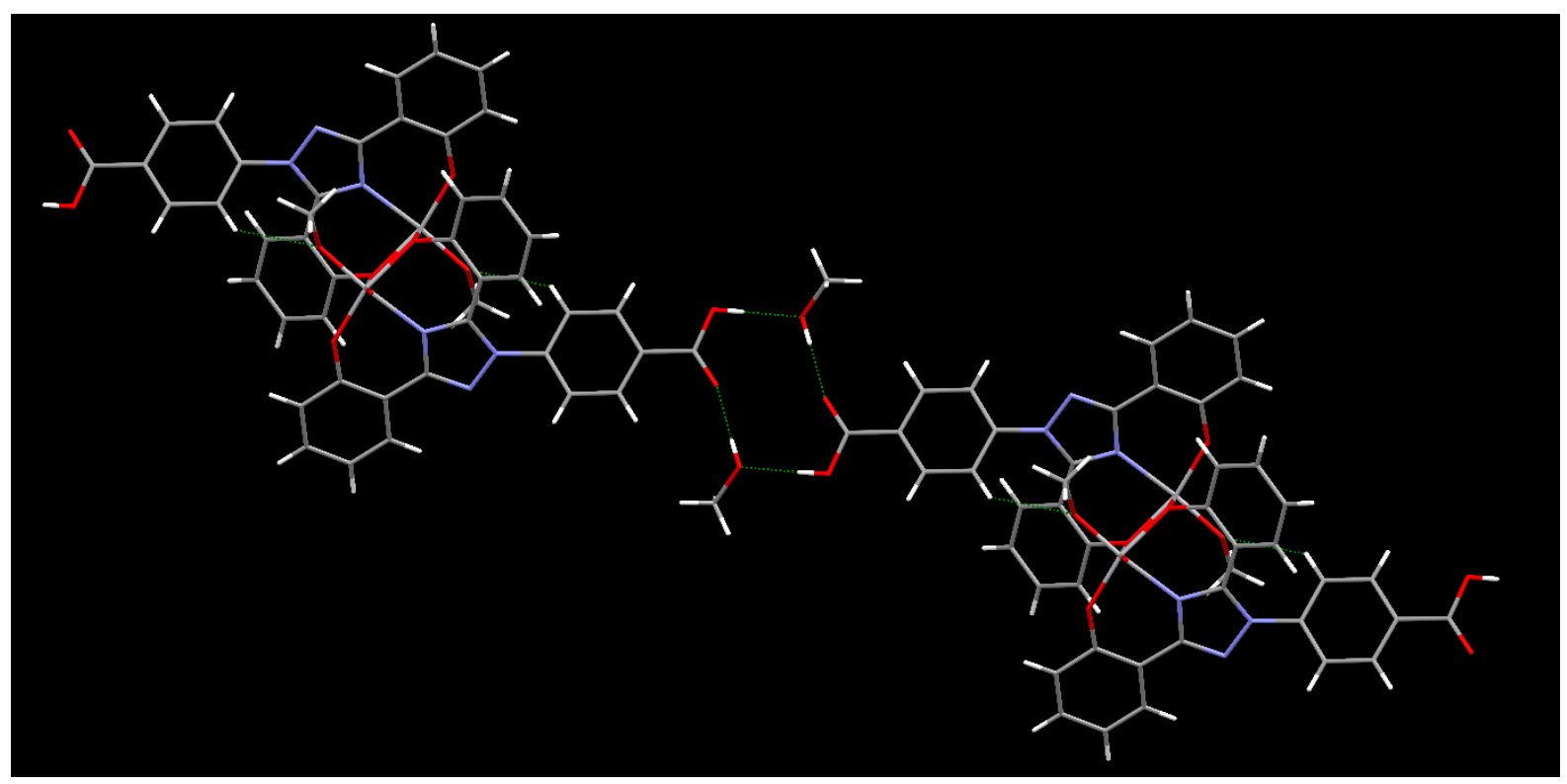

Figure 6. The $\mathrm{R}_{4}^{4}(12)$ embrace that forms hydrogen-bonded tapes within 5 . Dashed lines show $\mathrm{O}-\mathrm{H} \cdots \mathrm{O}$ hydrogen bonds.

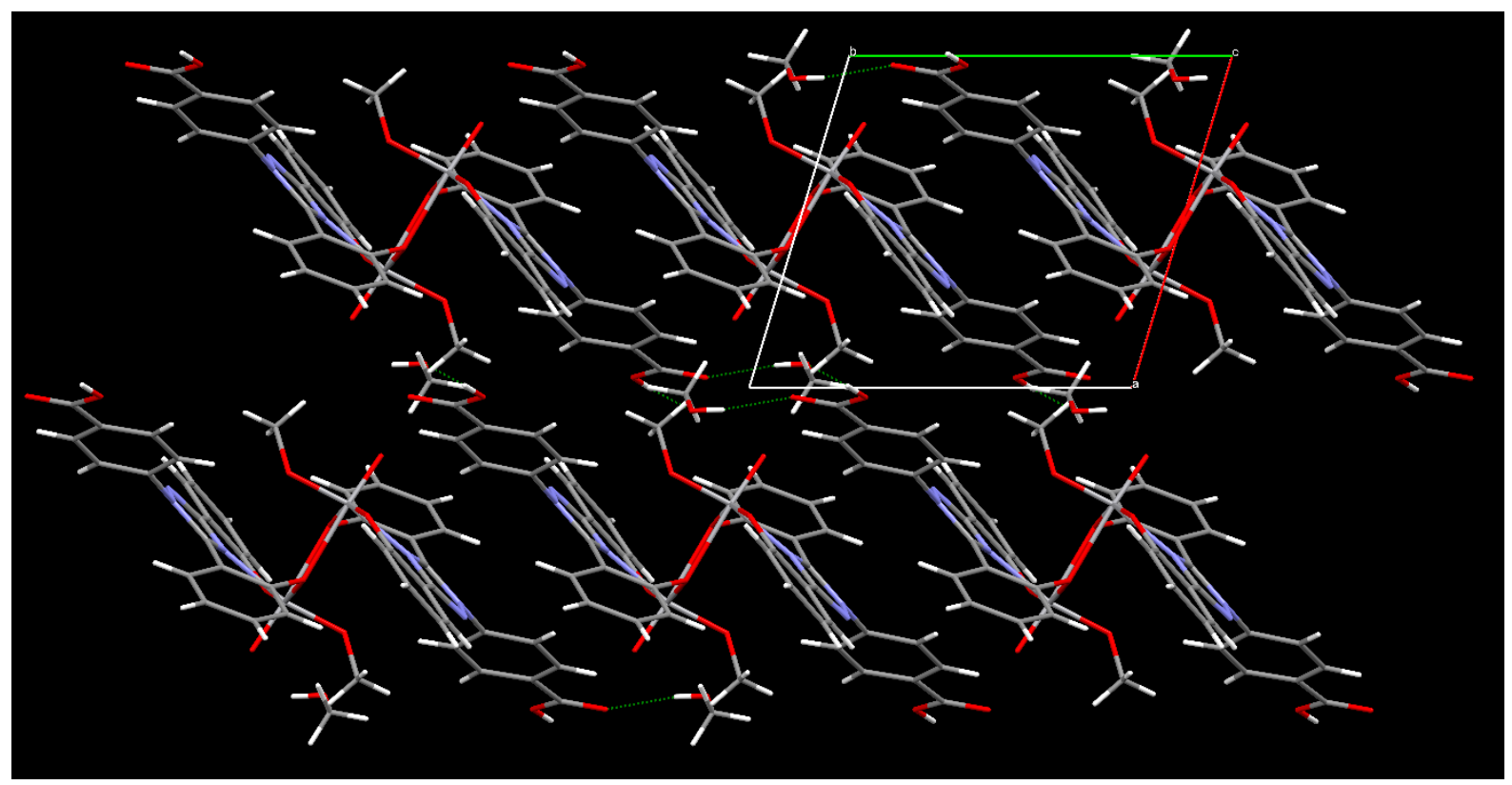

Figure 7. Packing of 5 in the solid state. Structure is viewed down the $c$-axis. Dashed lines show $\mathrm{O}-\mathrm{H} \cdots \mathrm{O}$ hydrogen bonds. 


\subsection{EPR spectroscopy}

The EPR spectrum of the oxidized form of $\mathbf{1}$ has previously been reported. [23] In powdered form, tetramer 2 exhibited a broad EPR spectrum (due to intermolecular interactions; ESI, Fig. S5): the ${ }^{51} \mathrm{~V}$ hyperfine structure $\left({ }^{51} \mathrm{~V}, 99.8 \%\right.$ natural abundance, nuclear spin $\left.I=7 / 2\right)$ was partially resolved in the second derivative spectrum (Fig. S5). As a fluid $\mathrm{CH}_{2} \mathrm{Cl}_{2}$ solution, an 8-line hyperfine pattern was observed (ESI, Fig. S6) with $\mathrm{A}_{\text {iso }}=295 \mathrm{MHz}$ and $\mathrm{g}_{\text {iso }}=1.973$, consistent with a simple V(IV), $\mathrm{d}^{1}$ oxidovanadium(IV) monomer and hence with the formulation of the dimer-of-dimer structures of $\mathbf{2}$ as $\left\{\mathrm{V}^{\mathrm{IV}} \mathrm{V}^{\mathrm{V}}\right\}_{2}$ where the two dimers are well separated and non-interacting. On freezing, the solution a poorly resolved spectrum was found (figure 8, top), possibly due to poor glassing (or slight precipitation) in this solvent. Sharp and broad signals were observed, but again characteristic of a V(IV) oxidovanadium(IV) monomer. A clean spectrum was obtained on recording the second derivative (figure 8, middle), and simulation (figure 8, bottom) gives axial g-values of $g_{z}=1.945, g_{x, y}=1.980$ with ${ }^{51} \mathrm{~V}$ hyperfine couplings of $A_{z}=517, A_{x, y}=190 \mathrm{MHz}$. These features match those from the powder spectrum (ESI, Fig. S7), consistent with similar structures in both phases. 


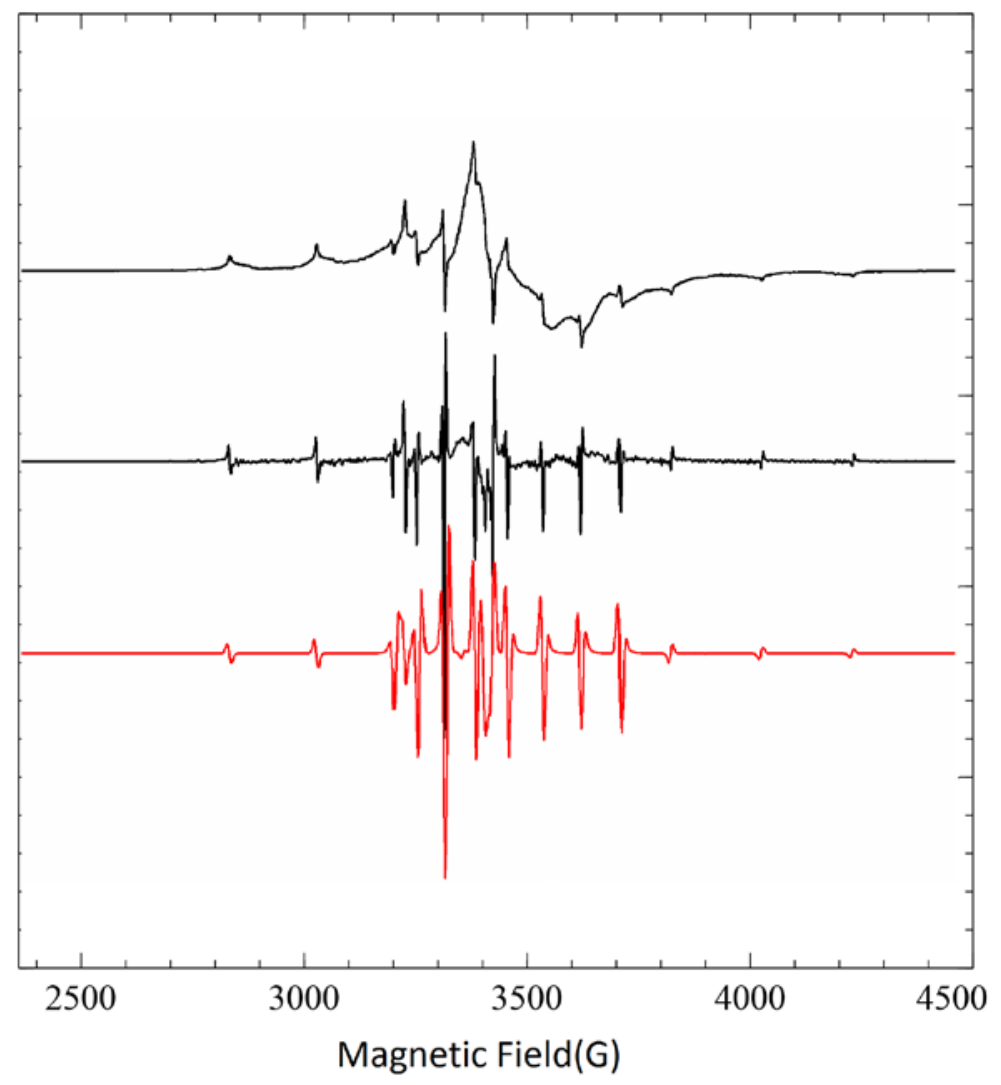

Figure 8. EPR of 2 in $\mathrm{CH}_{2} \mathrm{Cl}_{2}$ solution at $130 \mathrm{~K}$, presented as first (top) and second (middle) derivative spectra. Bottom: simulation of second derivative spectrum with the parameters in the text. 


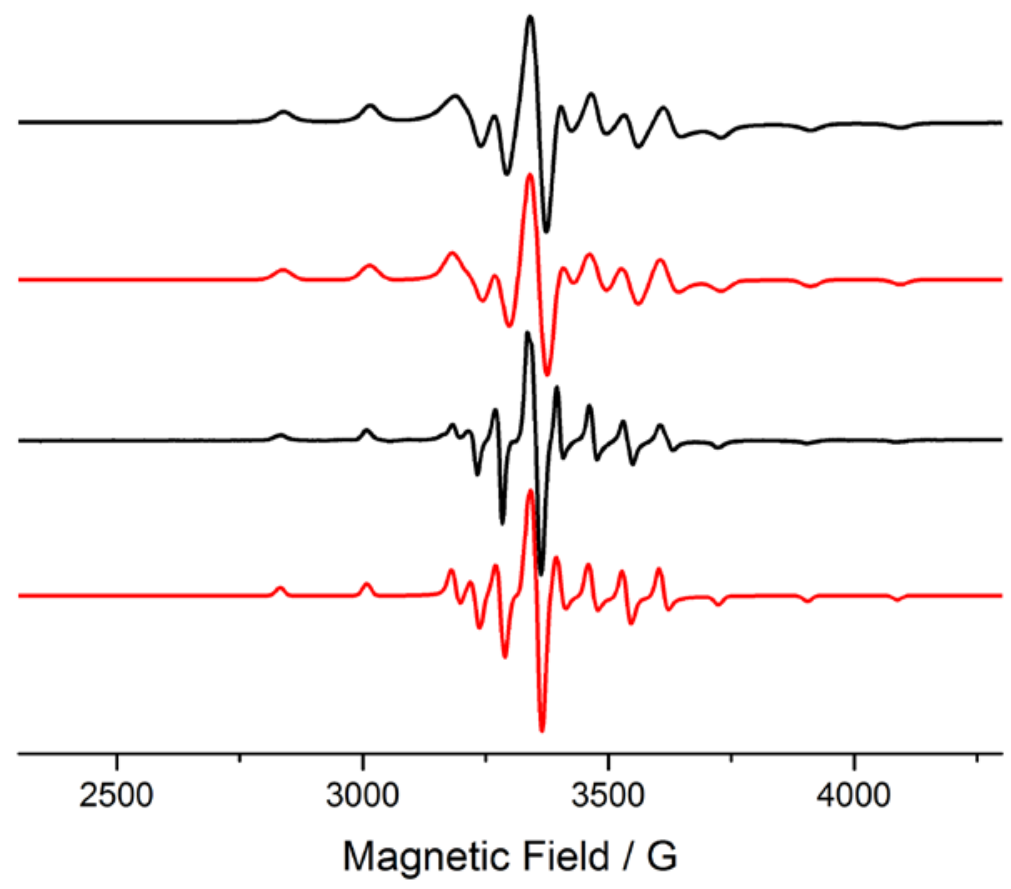

Figure 9. From top to bottom: experimental powder X-band EPR spectrum of $\mathbf{3}$ at room temperature (black; frequency $=9.4608 \mathrm{GHz}$ ) and simulation (red); experimental frozen $\mathrm{CH}_{2} \mathrm{Cl}_{2}$ solution X-band EPR spectrum at $150 \mathrm{~K}$ (black; frequency $=9.4776 \mathrm{GHz}$ ) and simulation (red).

In the case of 3, spectra of powders at room temperature and frozen solution (figure 9, top) were well resolved and gave identical $\mathrm{g}$ and A values $\left(g_{z}=1.952, g_{x, y}=1.983, A_{z}=490, A_{x, y}=165 \mathrm{MHz}\right)$, hence the structure is maintained in solution. The same is true for $\mathbf{4}$, giving very similar parameters of $g_{z}=$ 1.950, $g_{x, y}=1.982, A_{z}=495, A_{x, y}=172 \mathrm{MHz}$. The hyperfine coupling constants for 3 and 4 are significantly smaller than those of 2 : this is consistent with the $\mathrm{VO}_{4} \mathrm{~N}$ vs. $\mathrm{VO}_{5}$ coordination spheres. The resolution of hyperfine to only one ${ }^{51} \mathrm{~V}$ nucleus is consistent with the $\mathrm{V}(\mathrm{IV}) \mathrm{V}(\mathrm{V})$ formulation above, and is reminiscent of the situation observed by Chakravorty et al for the complex $\mathrm{Et}_{4} \mathrm{~N}_{2}\left[\mathrm{~V}_{2} \mathrm{O}_{3}(L \text {-asal })_{2}\right]$. 
[27a] We also note that for the complex $\left\{\left[\mathrm{V}^{\mathrm{V}} \mathrm{O}(\mathrm{L})\right]\left[\mathrm{V}^{\mathrm{IV}} \mathrm{O}(\mathrm{L})\right](\mu-\mathrm{O})\right\}$; , where $\mathrm{L}$ is an aroylazine, it was invoked that the unpaired electron is extensively delocalized between the two $\mathrm{V}$ centers in the formed mixed-valence complex; a similar situation is very likely for 3 and 4. [27b]

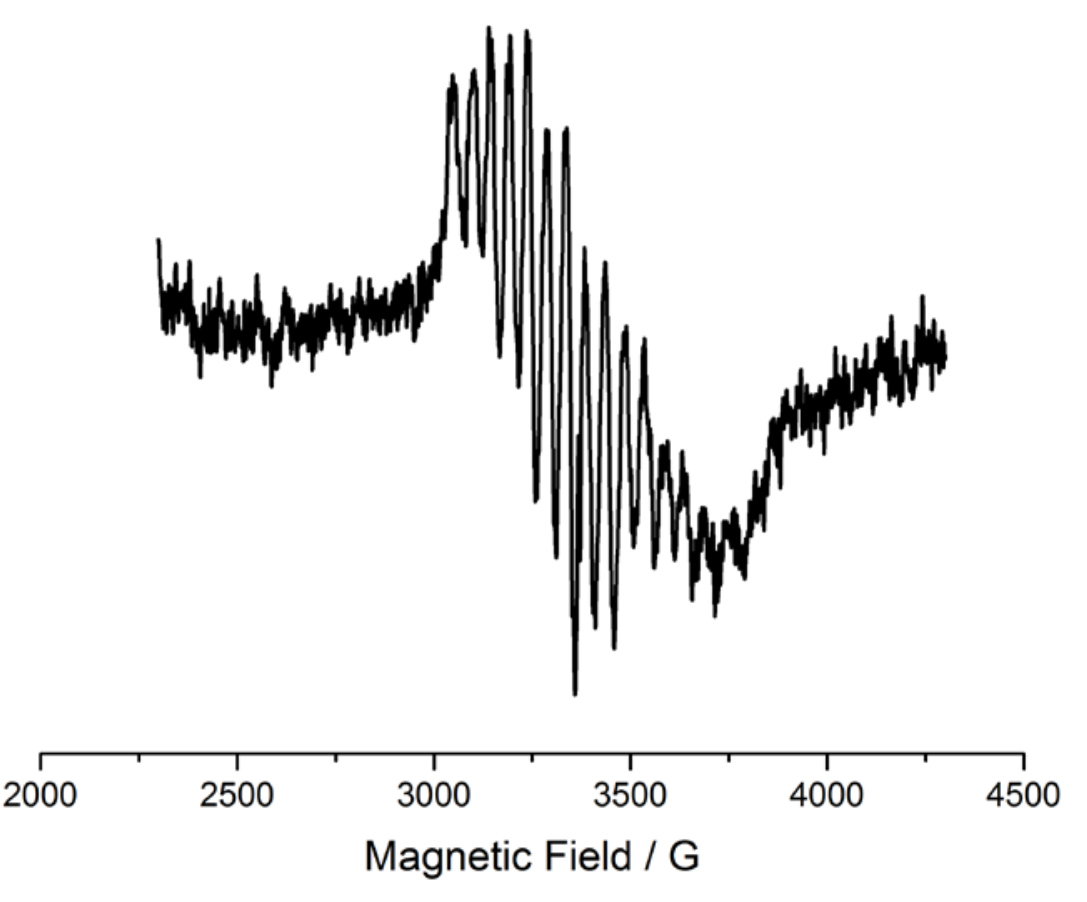

Figure 10. Room temperature $\mathrm{X}$-band EPR spectrum $(9.4526 \mathrm{GHz})$ of 3 as a $\mathrm{CH}_{2} \mathrm{Cl}_{2}$ solution.

At room temperature the solution sample gives a fairly weak, but well resolved, 15-line hyperfine splitting pattern (figure 10). The hyperfine splitting are approximately half the value expected for a $\mathrm{VO} 2+$ monomer, which is what is expected from coupling to two equivalent $\mathrm{I}=7 / 2$ nuclei $(2 \mathrm{nI}+1)$ as a result of exchange between the two vanadium ions. This confirms the dimeric structure in solution, however it is odd that this is not observed in the frozen solution or solid-state spectra. One possible explanation is that the exchange coupling is dependent of the temperature. 
The EPR spectra of vanadium complexes of biological relevance has been reviewed. [28]

\subsection{Cytotoxicity studies}

In order to evaluate the biological activity of complexes $\mathbf{1 - 4}$, cell viability assays were performed. The complexes were tested for their anti-proliferative activity against human brain glioblastoma (U87) cells. A 72 h time point was selected to maximise the cytotoxic effect, this was considered in comparison with some previous literature studies where $16 \mathrm{~h}$ and $48 \mathrm{~h}$ time points were used, but showed lower activity with these shorter incubation times. [29] There is significant variation in the cytotoxicity results reported in the literature with different cell lines and assay time points used, see examples included in Table 1.

The assay measurement was made after cells were incubated with the compounds for $72 \mathrm{~h}$ and is the result of the mitochondrial based reduction of a tetrazolium dye (MTS) to its formazan product. Different types of assays have previously been assessed for their relevance to determine biological activity profiles of vanadium complexes. [30] The $\mathrm{CC}_{50}$ values (molar amount of the complex required to reduce cell growth by 50\%) were determined, see Table 1 . The complexes synthesised give $\mathrm{CC}_{50}$ values that range from $57 \mu \mathrm{M}$ for 2 to $126 \mu \mathrm{M}$ for 3 showing comparatively low cytotoxicity.

The U87 cell line was selected due to the clinical importance of glioblastoma and the limited but promising data in the literature. [31] The most appropriate literature comparator compound for the U87 cell line is bis(4,7-dimethyl-1,10 phenanthroline) sulfatooxovanadium(IV) (METVAN) which has been investigated using U87 models both in vitro and in vivo. METVAN exhibits low micromolar cytotoxicity in vitro and has been shown to reduce tumour growth in vivo for implanted U87 tumours in mice.

Previously, a series of different cell lines have been used to analyse vanadium salts (including oxidovanadium(IV) sulfate) and compounds that are available for human administration. [29] Using longer assay time points and variation in cell lines, common vanadium salts can show potent cytotoxicity 
in tumour cells. The example comparator data presented in Table 1 is a strong indicator of the variation in results due to incubation time which may be related to solubility and could be affected by the media used. Compounds 1-4 show less potent cytotoxicity profiles, particularly in comparison with METVAN. A more comprehensive investigation to demonstrate cellular uptake properties and potential effect on other biological targets (e.g. protein binding) are required to better understand their properties and how they can be modified. It is likely that the complexes would be safe to administer in vivo, if evidence of efficacy was obtained. This study indicates that the compounds are not suitable for application as cytotoxic drugs against U87/ glioblastoma cancer, but it is possible that they could have other antitumour properties.

\begin{tabular}{cccc}
\hline Complex & $\begin{array}{c}\mathrm{CC}_{50}(\mu \mathrm{M}) 72 \mathrm{~h} \\
\text { U87 cells }[31]\end{array}$ & $\begin{array}{c}\mathrm{CC}_{50}(\mu \mathrm{M}) 24 \mathrm{~h} \\
\mathrm{CHO}-\mathrm{K} 1 \text { cells } \\
{[30,32]}\end{array}$ & $\begin{array}{c}\mathrm{CC}_{50}(\mu \mathrm{M}) 72 \mathrm{~h} \\
\text { BALB/3T3 cells } \\
{[33]}\end{array}$ \\
\hline $\mathbf{1}$ & 94 & - & - \\
$\mathbf{2}$ & 57 & - & - \\
$\mathbf{3}$ & 126 & - & - \\
$\mathbf{4}$ & 62 & - & - \\
$\mathrm{METVAN}^{(\mathrm{A}) \mathrm{VO}_{3} \dagger}$ & $2.1 / 16^{*}$ & - & - \\
$\mathrm{VOSO}_{4}$ & - & $\approx 100$ & $\approx 5$ \\
\hline
\end{tabular}

Table 1 - $\mathrm{CC}_{50}(\mu \mathrm{M})$ values of the VO complexes synthesised compared to literature data. [29-33]

*Assay at shorter time points $2.1 \mathrm{uM}$ at $48 \mathrm{~h}$ time point and $16 \mathrm{uM}$ at $16 \mathrm{~h} . \dagger \mathrm{A}=\mathrm{NH}_{4}{ }^{+}$ or $\mathrm{Na}^{+}$

\subsection{Experimental}

\subsection{General}

Elemental analyses were carried out at the University of Hull. Infrared spectra were recorded on a Nicolet iS5 FT-IR spectrometer. Mass spectra were obtained from the EPSRC National Mass Spectrometry Service Unit, Swansea. Compounds $\mathbf{L}^{2} \mathrm{H}_{4}, \mathbf{L}^{3} \mathrm{H}_{2}, \mathbf{L}^{4} \mathrm{H}_{2}$ and [VO(acac) $)_{2}$ and $\mathbf{1}$ were 
prepared using the previously reported methods. [23, 34-36] [VOCl $]$ ], $\left[\mathrm{VOSO}_{4}\right]$ and $\mathbf{L}^{1} \mathrm{H}_{3}$ were obtained from Sigma-Aldrich Company Ltd. and were used as received.

\subsection{Preparation of $\left.\left\{\left[\mathrm{VO}(\mathrm{acac})_{2}(\mathrm{OEt})\right](\mathrm{VO}) \mathbf{L}^{2}\right]\right\}_{2}(\mathbf{2})$}

To a stirred solution of oxidovanadium(IV) acetylacetonate $(1.78 \mathrm{~g}, 6.7 \mathrm{mmol})$ in anhydrous toluene (50 mL) was added 6,6-methylenebis(4-(tert-butyl)-2-(hydroxymethyl)phenol) (1.00 g, $2.7 \mathrm{mmol}$ ) in anhydrous toluene $(10 \mathrm{~mL})$. The resulting solution was refluxed for $48 \mathrm{~h}$ under an inert atmosphere $\left(\mathrm{N}_{2}\right)$. The volatiles were removed in vacuo and the dark green residue was extracted with warm anhydrous ethanol $(20 \mathrm{~mL})$. The resulting warm solution was filtered, and then left to stand at ambient temperature to afford small green crystals over a period of several weeks (0.84 g, 24 \%). Found: C, 55.93; $\mathrm{H}, 6.05 \%$. $\mathrm{C}_{60} \mathrm{H}_{80} \mathrm{O}_{18} \mathrm{~V}_{4}$ requires: C, 55.73; H, 6.24\%. MALDI-MS m/z $1292.12\left[\mathrm{M}^{+}\right] . v_{\max } / \mathrm{cm}^{-}$ ${ }^{1} 3398$ (br), 2962 (m), 1648 (w), 1588 (w), 1553 (w), 1519 (s), 1458 (w), 1416 (m), 1371 (s), 1356 (s), 1286 (m), 1259 (s), 1188 (w), 1088 (m), 1015 (s), 993 (s), 936 (m), 863 (m), 796 (s), 788 (s), 684 (s), $658(\mathrm{~m})$.

\subsection{Preparation of $\left[\mathrm{Et}_{3} \mathrm{NH}\right]\left[\mathrm{VO}(\mathrm{OMe}) \mathbf{L}^{3}\right]_{2}(3)$}

To a stirred suspension of 4-[3,5-bis(2-hydroxyphenyl)-1,2,4-triazol-1-yl]benzoic acid (0.50 g, 1.3 $\mathrm{mmol})$ in anhydrous acetonitrile (10 mL) was added triethylamine (5 drops) followed by vanadium(V) oxychloride $(0.15 \mathrm{~mL}, 1.6 \mathrm{mmol})$. The resulting solution was refluxed overnight under a nitrogen atmosphere. The volatiles were removed in vacuo and the remaining residue was extracted into anhydrous methanol $(20 \mathrm{ml})$. Following removal of methanol, the residue was taken up in tetrahydrofuran $(20 \mathrm{~mL})$. This solution was filtered under an inert atmosphere and concentrated to $c a$. half its original volume. This solution was left to stand at $-20^{\circ} \mathrm{C}$ for $48 \mathrm{~h}$ upon which dark blue crystals formed (0.37 g, 65\%). Found: C, 58.46; H, 5.41; N, 9.52\%. $\mathrm{C}_{53} \mathrm{H}_{55} \mathrm{~N}_{7} \mathrm{O}_{12} \mathrm{~V}_{2}$ requires: C, 58.73; H, 5.11; N, 9.05\%. MALDI-MS m/z 875.99 [M+']. $v_{\max } / \mathrm{cm}^{-1} 3411$ (w, br), 2979 (w, br), 2605 (w, br), 2496 (w, 
br),1769 (w), 1705 (m), 1600 (s), 1568 (m), 1527 (w), 1514 (w), 1476 (w), 1460 (s), 1397 (m), 1364 (w), 1308 (m), 1265 (w), 1251 (w), 1150 (m), 1097 (w), 1088 (w), 1034 (s), 1015 (w), 981 (m), 959 (s), 856 (s), 839 (w), 799 (m), $779(\mathrm{w}), 757$ (s), 719 (m), $702(\mathrm{~m}), 645$ (w), 627 (w), $613(\mathrm{w})$.

\subsection{Preparation of $\left[\mathrm{Et}_{3} \mathrm{NH}\right]\left[\mathrm{VO}(\mathrm{OMe}) \mathbf{L}^{4}\right]_{2}(4)$}

To a stirred suspension of 4-[3,5-bis(2-hydroxyphenyl)-1,2,4-triazol-1-yl]benzosulfonic acid (0.50 g, $1.2 \mathrm{mmol})$ in anhydrous acetonitrile $(10 \mathrm{~mL})$ was added triethylamine (5 drops) followed by vanadium(V) oxychloride $(0.14 \mathrm{~mL}, 1.4 \mathrm{mmol})$. The resulting solution was refluxed overnight under a nitrogen atmosphere. The volatiles were removed in vacuo and the remaining residue was extracted into anhydrous methanol $(20 \mathrm{ml})$. Following removal of the methanol, the residue was taken up in tetrahydrofuran $(20 \mathrm{~mL})$. This solution was filtered and concentrated to $c a$. half its original volume. This solution was left to stand at $-20^{\circ} \mathrm{C}$ for $48 \mathrm{~h}$ to afford a dark blue precipitate ( $\left.0.32 \mathrm{~g}, 56 \%\right)$. Found: C, 52.00; H, 3.05; N, 8.46\%. $\mathrm{C}_{40} \mathrm{H}_{26} \mathrm{~N}_{6} \mathrm{O}_{12} \mathrm{~S}_{2} \mathrm{~V}_{2} \cdot 1\left(\mathrm{C}_{4} \mathrm{H}_{8} \mathrm{O}\right)$ requires: C, 51.77; $\mathrm{H}, 3.36 ; \mathrm{N}, 8.23 \%$. MALDI-MS m/z 948.03 [M+]. $v_{\max } / \mathrm{cm}^{-1} 3410$ (w, br), 1599 (s), 1567 (m), 1526 (w), 1513 (w), 1497 (w), 1478 (m), 1459 (s), 1450 (w), 1399 (m), 1357 (m), 1322 (w), 1302 (m), 1264 (w), 1251 (w), 1174 (s), 1123 (s), 1101 (m), 1066 (w), 1032 (s), 1012 (s), 991 (w), 982 (m), 962 (s), 863 (s), 842 (m), 764 (w), $750(\mathrm{~s}), 731(\mathrm{w}), 717(\mathrm{w}), 705(\mathrm{~m}), 698(\mathrm{w}), 651(\mathrm{~m}), 633(\mathrm{~s}), 619(\mathrm{~m})$.

\subsection{Preparation of $\left[\mathrm{VO}(\mathrm{OMe}) \mathbf{L}^{3}\right]_{2}(5)$}

To a stirred suspension of 4-[3,5-bis(2-hydroxyphenyl)-1,2,4-triazol-1-yl]benzoic acid (1.00 g, 2.6 $\mathrm{mmol})$ in anhydrous acetonitrile $(25 \mathrm{~mL})$ was added oxidovanadium(IV) sulfate $(0.42 \mathrm{~g}, 2.6 \mathrm{mmol})$. The resulting solution was refluxed overnight under a nitrogen atmosphere. The volatiles were removed in vacuo and the remaining residue was extracted into anhydrous methanol $(20 \mathrm{ml})$. Following removal of any remaining undissolved solid, the solution was concentrated to $c a .5 \mathrm{~mL}$ and a layer of anhydrous dichloromethane $(5 \mathrm{~mL})$ was added. The two layers were allowed to diffuse over several weeks yielding dark brown crystals (0.51 g, 42 \%). Found: C, 56.42; H, 3.35; N, 8.98\%. $\mathrm{C}_{44} \mathrm{H}_{32} \mathrm{~N}_{6} \mathrm{O}_{12} \mathrm{~V}_{2}$ requires: C, 
56.30; H, 3.44; N, 8.95\%. MALDI-MS m/z 938.22 [M+ ${ }^{+}{ }^{1} \mathrm{H}\left(400 \mathrm{MHz}\right.$; $\left.\mathrm{CD}_{3} \mathrm{CN}\right) \delta 10.55-8.30$ (very broad s, 1H, $\left.\mathrm{CO}_{2} \mathrm{H}\right), 8.24$ (4 H, t), 7.98 (1 H, d), $7.73(1 \mathrm{H}, \mathrm{d}), 7.65$ (2 H, d), 7.56 (2 H, d), $7.51(1 \mathrm{H}, \mathrm{t})$, 7.31-7.39 (2 H, m), 7.17 (1 H, t), 7.09 (1 H, t), 7.03 (1 H, t), 6.97 (1 H, d), $6.91(1 \mathrm{H}, \mathrm{d}), 6.81(3 \mathrm{H}, \mathrm{t})$, 6.63-6.71 (2 H, m), 6.58 (1 H, d) - all arylH (for expansion, see figure S6, ESI), $3.28(6 \mathrm{H}, \mathrm{s}, \mathrm{OMe}) .{ }^{51} \mathrm{~V}$ (105 MHz; D4-MeOH) $\delta$-579.61 (d).

\subsection{Cytotoxicity studies}

Human glioblastoma cell line (U87) from ATCC and grown in DMDM media. All the media were purchased from Lonza. Complete media was made by the addition of $10 \%(\mathrm{v} / \mathrm{v})$ heat inactivated fetal bovine serum (FBS) (Biowest, France), 1\% (v/v) penicillin and streptomycin (100 units $/ \mathrm{ml}$ ) antibiotic. All the cell culture was maintained at $37^{\circ} \mathrm{C}$ in a humidified, $\mathrm{CO}_{2}(5 \%)$ controlled atmosphere with sub culturing carried out every 2-3 days as appropriate. Cells were incubated with the compounds in a multi-well plate (triplicate) with at least eight different concentrations for $72 \mathrm{~h}$ before determining their mitochondrial based reduction of a tetrazolium dye (MTS) to a formazan product $(490 \mathrm{~nm})$.

\subsection{X-ray crystallography}

X-ray diffraction data were collected for 2 using a Stoe IPDS2 image plate diffractometers using Mo K $\alpha$ radiation. The crystal was mounted at the end of a glass fibre and held at $150 \mathrm{~K}$ during data collection using an Oxford Cryosystems nitrogen gas cryostream. The structure was solved using Superflip [37] and refined against $\mathrm{F}^{2}$ using SHELXL-2014. [38] The crystal examined was weakly scattering but allowed definitive determination of the molecular arrangement.

X-ray diffraction data for $\mathbf{3}$ and $\mathbf{5}$ were collected by the EPSRC Crystallography Service using a rotating anode source and Rigaku Saturn detector with samples held at $100 \mathrm{~K}$ in a cryostream. The structures were solved using SHELXT [38] and refined using SHELXL-2014. 


\section{X-ray crystallography}

Table 2. Crystal structure data for complexes 2, 3 and 5.

\begin{tabular}{|c|c|c|c|}
\hline Compound & 2 & 3 & 5 \\
\hline Formula & $\mathrm{C}_{117} \mathrm{H}_{149.5} \mathrm{O}_{36} \mathrm{~V}_{8}$ & $\mathrm{C}_{55} \mathrm{H}_{57} \mathrm{~N}_{7} \mathrm{O}_{15} \mathrm{~V}_{2}$ & $\mathrm{C}_{23} \mathrm{H}_{20} \mathrm{~N}_{3} \mathrm{O}_{7} \mathrm{~V}$ \\
\hline Formula weight & 2539.38 & 1157.95 & 501.36 \\
\hline Crystal system & Monoclinic & Monoclinic & Triclinic \\
\hline $\begin{array}{l}\text { Space group } \\
\text { Unit cell } \\
\text { dimensions }\end{array}$ & $P 2_{1} / m$ & $P_{C}$ & P-1 \\
\hline$a(\AA)$ & $12.280(2)$ & $9.4363(7)$ & $9.2829(4)$ \\
\hline$b(\AA)$ & $34.344(6)$ & $10.8679(8)$ & $10.1708(4)$ \\
\hline$c(\AA)$ & 18.192(3) & 26.8741(19) & $12.4115(3)$ \\
\hline$\alpha(\AA)$ & 90.00 & 90.00 & $85.393(2)$ \\
\hline$\beta(\AA)$ & $91.276(15)$ & $97.559(3)$ & 81.001(3) \\
\hline$\gamma(\AA)$ & 90.00 & 90.00 & $72.752(4)$ \\
\hline$V\left(\AA^{3}\right)$ & 7671.(2) & 2732.1(3) & 1104.64(7) \\
\hline$Z$ & 2 & 2 & 2 \\
\hline Temperature (K) & 293(2) & $100(2)$ & $100(2)$ \\
\hline Wavelength $(\AA)$ & 0.71073 & 0.71073 & 0.71073 \\
\hline $\begin{array}{c}\text { Calculated } \\
\text { density (Mg m- } \\
3 \text { ) }\end{array}$ & 1.099 & 1.408 & 1.507 \\
\hline $\begin{array}{c}\text { Absorption } \\
\text { coefficient }\left(\mathrm{mm}^{-}\right. \\
1 \text { ) }\end{array}$ & 0.527 & 0.417 & 0.500 \\
\hline$\theta(\max )\left(^{\circ}\right)$ & 18.848 & 27.515 & 27.485 \\
\hline $\begin{array}{c}\text { Reflections } \\
\text { measured }\end{array}$ & 7496 & 28561 & 22464 \\
\hline $\begin{array}{l}\text { Unique } \\
\text { reflections }\end{array}$ & 5203 & 10578 & 5022 \\
\hline$R_{i n t}$ & 0.2150 & 0.0678 & 0.0494 \\
\hline $\begin{array}{l}\text { Number of } \\
\text { parameters }\end{array}$ & 758 & 714 & 324 \\
\hline$R_{1}\left[F^{2}>2 \sigma\left(F^{2}\right)\right]$ & 0.0840 & 0.1113 & 0.0375 \\
\hline$w R_{2}$ (all data) & 0.2014 & 0.2911 & 0.0931 \\
\hline $\begin{array}{l}\text { GOOF, } S \\
\text { Largest }\end{array}$ & 0.695 & 1.081 & 1.015 \\
\hline $\begin{array}{l}\text { difference peak } \\
\text { and hole }\left(\mathrm{e} \AA^{-3}\right)\end{array}$ & 0.336 and -0.241 & 1.345 and -1.415 & 0.369 and -0.401 \\
\hline
\end{tabular}




\section{Conclusion}

In conclusion, we have synthesized and structurally characterised a series of high valent oxidovanadium complexes bearing either chelates derived hydroxymethyl/phenols or triazol proligands. EPR measurements were used to investigate the electronic interactions. Biological screening (cell viability assays) showed low cytotoxicity indicating application of these compounds to treatment of U87 human glioblastoma models is not appropriate. Further investigation of the factors that may be affecting this (including cellular uptake) and the screening of a wider range of cancer cell lines is required. The complexes may also be of relevance to other disease states in which vanadium complexes have been shown to be active, such as hypertension.

\section{Appendix A.}

Supplementary data CCDC 1875986-1875988 contains the supplementary crystallographic data for $<$ <yy $>$. These data can be obtained free of charge viahttp://www.ccdc.cam.ac.uk/conts/retrieving.html, or from the Cambridge Crystallographic Data Centre, 12 Union Road, Cambridge CB2 1EZ, UK; fax: (+44) 1223-336-033; or email: deposit@ccdc.cam.ac.uk.

\section{Acknowledgements}

We would like to thank the EPSRC UK National Crystallography Service at the University of Southampton for the collection of data (complexes 3 and 5). The EPSRC Mass Spectrometry 
Service Centre at Swansea is thanked for the collection of mass spectra. CR thanks the Whitelaw Frater Cancer Trust for financial support.

\section{References}

[1] See for example, (a) H. Hagen, J. Boersma, G. van Koten, Chem. Soc. Rev. 31 (2002) 357; (b) C. Redshaw, Dalton Trans. 39, (2010) 5595; (c) K. Nomura, S. Zhang, Chem. Rev. 111 (2011) 2342; (d) J. -Q. Wu, Y. -S. Li, Coord. Chem. Rev. 255 (2011) 2303; (e) C. Wu, F. Feng, Y. Xie, Chem. Soc. Rev. 42 (2013) 5157. (f) M. Debnath, M. Dolai, K. Pal, A. Dutta, H. M. Lee, M. Ali, Inorg. Chimica Acta, 480 (2018) 149; (g) M. S. Maru, S. Barroso, P. Adão, L. G. Alves, A. M. Martins, J. Organomet.

Chem. 870 (2018) 136; (h) S. Dekar, K. Ouari, S. Bendia, D. Hannachi, J. Weiss, J. Organomet. Chem. 866 (2018) 165; (i) A. K. Srivastava, S. Ghosh, S. Jana, S. Pal, Inorg. Chimica Acta, 483 (2018) 329. [2] (a) D. Rehder, Coord. Chem. Rev. 182 (1999) 297; (b). K. H. Thompson, J. H. McNeill, C. Orvig, Chem. Rev. 99 (1999) 2561; (c). K. H. Thompson, C. Orvig, Coord. Chem. Rev. 219-221 (2001), 1033; (d) H. Sakurai, Y. Kojima, Y. Yoshikawa, K. Kawabe, H. Yasui, Coord. Chem. Rev. 226 (2002) 187; (e) D. C. Crams, J. J. Smee, E. Gaidamauskas, L. Yang, Chem. Rev. 104 (2004) 849; (f) O. Bortolini, V. Conte, J. Inorg. Biochem. 99 (2005) 1549; (g) T. Kiss, T. Jakusch, D. Hollender, Á. Dörnyei, É. A. Enyedy, J. C. Pessoa, H. Sakurai, A. Sanz-Medel, Coord. Chem. Rev. 252 (2008) 1153; (h) D. Gambino Coord. Chem. Rev. 255 (2011) 2193; (i) D. C. Crans, A. M. Trujillo, P. S. Pharazyn, M. D. Cohen, Coord. Chem. Rev. 255 (2011) 2178; (j) T. Jakusch, J. C. Pessoa, T. Kiss, Coord. Chem. Rev. 255 (2011) 2218; (k) G. R. Willsky, L. -H. Chi, M. Godzala III, P. J. Kostyniak, J. J. Smee, A. M. Trujillo, J. A. Alfano, W. Ding, Z. Hu, D. C. Crans, Coord. Chem. Rev. 255 (2011) 2258;

(l) Vanadium: Biochemical and Molecular Biological Approaches. Ed. H. Michibata, Springer Dordrecht Heidleberg London New York, 2012; (m) J. C. Pessoa, S. Etcheverry, D. Gambino, Coord. Chem. Rev. 301-302 (2015) 24; (n) J. C. Pessoa, E. Garribba, M. F. A. Santos, T. Santos-Silva, Coord. 
Chem. Rev. 301-302 (2015) 49; (o) J. Korbecki, I. Baranowska-Bosiacka, I. Gutowska, D. Chlubek, Acta Biochimica Pol. 59 (2012) 195; (p) D. Rehder, Metallomics 7 (2015) 730.

[3] (a) M. J. Hannon, Pure Appl. Chem., 79 (2007) 2243; (b) B. Desoize, Anticancer Res., 24 (2004) 1529.

[4] T. Schilling, K. B. Keppler, M. E. Heim, G. Niebch, H. Dietzfelbinger, J. Rastetter, A. -R. Hanauske, Invest. New Drugs, 13, 327-332.

[5] E. Kioseoglou, S. Petanidis, C. Gabriel, A. Salifoglou, Coord. Chem. Rev. 301-302 (2015) 87.

[6] R. Faure, M. Vincent, M. Dufour, A. Shaver, B. I. Posner, J. Cell. Biochem., 59 (1995) 389.

[7] M. -M. Krady, S. Freyermuth, P. Rogue, A. N. Malviya, FEBS Lett., 412 (1997) 420.

[8] A. Morinville, D. Maysinger, A. Shaver, Trends Pharmacol. Sci., 19 (1998) 452.

[9] N. C. C. Huang, W. Y. Ma, Z. Dong, Int. J. Oncol., 13 (1998) 711.

[10] M. Ding, J.-J. Li, S. S. Leonard, J.-P. Ye, X. Shi, N. H. Colburn, V. Castranova, V. Vallyathan, Carcinogenesis, 20 (1999) 663.

[11] S. K. Pandey, J.-L. Chiasson, A. K. Srivastava, Mol. Cell. Biochem., 153 (1995) 69.

[12] J. A. Gordon, in Methods in Enzymology, Academic Press, 201 (1991) 477.

[13] C. M. Krejsa, S. G. Nadler, J. M. Esselstyn, T. J. Kavanagh, J. A. Ledbetter, G. L. Schieven, J. Biol. Chem., 272 (1997) 11541.

[14] K. H. Lau, D. J. Baylink, Crit. Rev. Oncog., 4 (1993) 451.

[15] C. M. Krejsa, G. L. Schieven, Environ. Health Perspect., 106 (1998) 1179.

[16] C. Kanik-Ennulat and N. Neff, Mol. Cell. Biol., 10 (1990) 898.

[17] M. Colin, C. Madoulet, N. Baccard, F. Arsac, J. C. Jardillier, Anticancer Res., 14 (1994) 2383.

[18] R. H. Maier, S. M. Purser, D. L. Nicholson, W. J. Pories, In Vitro Cell. Dev. Biol. Anim., 33 (1997) 218. 
[19] L. J. Hernádez-Benítez, P. Jiménez-Cruz, K. E. Cureño-Hernádez, A. Solano-Peralta, M. FloresĂlamo, A. Flores-Parra, I. Gracia-Mora, S. E. Castillo-Blim, Inorg. Chimica Acta, 480 (2018) 197.

[20] M. R. Maurya Coord. Chem. Rev. 237 (2003) 163.

[21] C. Redshaw, M. R. J. Elsegood, J. A. Wright, H. Baillie-Johnson, T. Yamato, S. D. Giovanni, A. Mueller, Chem. Comm., 48 (2012) 1129.

[22] S. Salehi, A. S.Saljooghi, A. Shiri, Eur. J. Pharmacol., 781 (2016) 209.

[23] P. B. Chatterjee, A. Audhya, S. Bhattacharya, S. M. T. Abtab, K. Bhattacharya, M. Chaudhury, J. Am. Chem. Soc. 132 (2010) 15842.

[24] (a) M. Mikuriya, M. Fukutani, D. Yoshioka, X-ray Struct. Anal. Online, 31 (2015) 33; (b) M. Mikuriya, M. Fukutani, M. Omote, D. Yoshioka, R. Mitsuhashi, X-ray Struct. Anal. Online, 32 (2016) 15.

[25] See for example, (a) M. Moon, M. Pyo, Y. C. Myoung, C. I. Ahn, M. S. Lah, Inorg. Chem. 40 (2001) 554; (b) Y. Inoue, S. Kodama, N. Taya, H. Sato, K. Oh-ishi, Y. Ishii, Inorg. Chem. 57 (2018) 7491 and references therein.

[26] W. Addison, T. N. Rao, J. Reedijk, J. van Rijn, and G. C. Verschoor, J. Chem. Soc., Dalton Trans. (1984) 1349.

[27] (a) S. Mondal, P. Ghosh, A. Chakravorty, Inorg. Chem. 36 (1997) 59. (b) S. P. Dash, S. Roy, M. Mohanty, M. F. N. N. Carvalho, M. L. Kuznetsov, J. C. Pessoa, A. Kumar, Y. P. Patil, A. Crochet, and R. Dinda, Inorg. Chem. 55, (2016) 8407.

[28] (a) T. S. Smith III, R. loBrutto, V. L. Pecoraro, Coord. Chem. Rev. 228 (2002) 1; (b) J. Krzystek, A. Ozarowski, J. Telser, D. C. Crans, Coord. Chem. Rev. 301-302 (2015) 123.

[29] A. Levina, P. A. Lay, Chem. Asian J. 12 (2017) 1692.

[30] I. Zwolak, Toxicol. Ind. Health 31 (2015) 677. 
[31] R. K. Narla, C. L. Chen, Y. Dong, F. M. Uckun, Clin. Cancer Res. 7 (2001) 2124.

[32] I. Zwolak, Toxicol. Ind. Health 32 (2016) 1013.

[33] E. Sabbioni, G. Pozzi, A. Pintar, L. Casella, S. Garattini, Carcinogenesis 12 (1991) 47.

[34] B. Dhawan, C. D. Gutsche, J. Org. Chem. 48 (1983) 1536.

[35] S. Steinhauser, U. Heinz, M. Bartholomä, T. Weyhermüller, H. Nick, K. Hegetschweiler, Eur. J. Inorg. Chem. (2004) 4177.

[36] R. A. Rowe, M. M. Jones, Inorg. Synth. 5 (1997) 113.

[37] L. Palatinus, G. Chapuis: Superflip - a computer program for the solution of crystal structures by charge flipping in arbitrary dimensions. J. Appl. Cryst. 40 (2007) 786.

[38] G. M. Sheldrick, Acta Cryst. C71 (2015) 3. 